\title{
Calretinin Expression in the Mammalian Neocortex: A Review
}

\author{
F. BARINKA ${ }^{1}$, R. DRUGA ${ }^{1,2,3}$
}

${ }^{1}$ Department of Anatomy, Charles University in Prague, Second Faculty of Medicine, Prague, Czech Republic, ${ }^{2}$ Department of Anatomy, Charles University in Prague, First Faculty of Medicine, Prague, Czech Republic, ${ }^{3}$ Department of Developmental Epileptology, Institute of Physiology, Academy of Sciences of the Czech Republic, Prague, Czech Republic

Received November 4, 2009

Accepted March 12, 2010

On-line April 20, 2010

\begin{abstract}
Summary
In the mammalian neocortex, the calcium-binding protein calretinin is expressed in a subset of cortical interneurons. In the recent years, research on interneurons is one of the most rapidly growing fields in neuroscience. This review summarizes the actual knowledge of the functions of calretinin in neuronal homeostasis and particularly of the distribution, connectivity and physiological properties of calretinin expressing interneurons in the neocortex of rodents and primates, including humans. The possible neuroprotective role of calretinin and the presumed "resistance" of calretinin-expressing interneurons to various pathological processes are also discussed.
\end{abstract}

\section{Key words}

Calcium-binding proteins • Interneurons • Inhibition • Neuroprotection • Neurovascular coupling

\section{Corresponding author}

Rastislav Druga, Department of Anatomy, Charles University in Prague, 2nd Faculty of Medicine, U Nemocnice 3, 12800 Prague, Czech Republic. Fax: +420 224965770 . E-mail: rastislav.druga@If1.cuni.cz; anatomie@lfmotol.cuni.cz

\section{Introduction}

Neuronal population in mammalian cerebral cortex consists of two distinct groups. Pyramidal neurons, which constitute approximately $70-80 \%$ of total neuronal population, are uniformly excitatory, using glutamate as a neurotransmitter. The other group is formed by interneurons, also known as local circuit neurons. Most of them are inhibitory, using GABA as a principal neurotransmitter. It is now increasingly appreciated that the GABAergic interneurons play many important roles in cortical neuronal networks both in normal and pathological states. Various strategies to sort GABAergic interneurons into distinct subgroups have been adopted and this process is far from being completed yet. Based on the expression of three different calcium-binding proteins, namely parvalbumin (PV), calbindin D28k (CB) and calretinin $(\mathrm{CR})$, it is possible to divide the cortical GABAergic interneurons into three largely non-overlapping populations (with some limitations, see below). Here we focus on $\mathrm{CR}$ and especially on $\mathrm{CR}$-expressing cortical neurons in the neocortex.

\section{EF-hand family of calcium-binding proteins}

Calretinin belongs to the so-called EF-hand family of CaBP. The EF-hand is an evolutionary well preserved amino acid domain with a characteristic threedimensional structure and with a high affinity for calcium ions (Moews and Kretsinger 1975). More than 600 proteins containing EF-hand motive are already known across different species (Carafoli et al. 2001). The best known is probably calmodulin, which mediates numerous intracellular processes after binding of $\mathrm{Ca}^{2+}$, hence acting like a $\mathrm{Ca}^{2+}$ sensor. The $\mathrm{Ca}^{2+}$ sensors are intracellular proteins, which after binding of free calcium ions undergo conformational change and subsequently activate or deactivate various target molecules (enzymes, transport proteins, etc.), thereby affecting various 
regulatory processes in the cell. On the contrary, $\mathrm{Ca}^{2+}$ buffers are another group of cytosolic $\mathrm{Ca}^{2+}$-binding proteins, which do not show any significant conformational change upon $\mathrm{Ca}^{2+}$ binding. $\mathrm{Ca}^{2+}$ buffers are involved in shaping both the amplitude and the duration of $\mathrm{Ca}^{2+}$ signals and in limiting the spatial spreading of local $\mathrm{Ca}^{2+}$ signals (Berridge et al. 2000, Schwaller 2009).

\section{Calretinin}

Calretinin, first described in 1987, acquired its name based on the structural similarity to calbindin D28k and the site of first detection (retina) (Rogers 1987). Calretinin in general shares many features with calbindin D28k and belongs to calbindin D28k subfamily of CaBP. The gene for CR is located on chromosome 16 (Parmentier et al. 1991). CR is composed of 269-271 amino acid residues and contains six EF-hand domains. Four of them bind $\mathrm{Ca}^{2+}$ with high affinity in a cooperative manner, one with low affinity and the last one is non-functional, without $\mathrm{Ca}^{2+}$-binding ability (Schwaller et al. 1997, Stevens and Rogers 1997). Besides $\mathrm{Ca}^{2+}$-binding properties, CR also shows affinity for copper ion $\mathrm{Cu}^{2+}$ (Groves and Palczewska 2001), which upon binding to $\mathrm{CR}$ antagonizes $\mathrm{Ca}^{2+}$ binding to $\mathrm{CR}$. The mammalian neuronal cytoplasmic concentration of $\mathrm{CR}$ was estimated to be in order of tens of micromoles (Hackney et al. 2005). Although usually considered to be freely diffusible and uniformly distributed in the cytoplasm, at a certain stage of development it was shown to be highly concentrated beneath the cell membrane (Hack et al. 2000).

While PV acts as a so-called "slow" buffer (exerts slow $\mathrm{Ca}^{2+}$ binding kinetics) and $\mathrm{CB}$ like a "fast" buffer (exerts fast $\mathrm{Ca}^{2+}$ binding kinetics), $\mathrm{CR}$ was first shown to behave as a fast buffer in modifying presynaptic signaling in frog saccular hair cells (Edmonds et al. 2000). However, recently it was found that CR shares some kinetic properties of both slow and fast buffers in modifying dendritic $\mathrm{Ca}^{2+}$ transients (Faas et al. 2007). Such dual kinetic properties are mainly consequence of the above-mentioned cooperative $\mathrm{Ca}^{2+}$ binding by $\mathrm{CR}$. These studies also show that $\mathrm{CR}$ affects intracellular calcium signals both pre- and postsynaptically. Further elucidation of $\mathrm{CR}$ function came from the studies on CR-/- (Schurmans et al. 1997, Schiffmann et al. 1999, Gall et al. 2003, Cheron et al. 2004, 2005), CR+/- (Gurden et al. 1998) and CR "rescue" (CR-/- with selective reexpression in certain cellular population) (Aller et al. 2003, Bearzatto et al. 2006) mice. In these studies, impairment of long-term potentiation in the dentate gyrus and especially abnormal excitability in the cerebellar neuronal network with mild impairment of motor coordination were shown to be a result of CR deficiency in mossy cells of dentate gyrus and granule cells of cerebellar cortex, respectively. Together, these studies indicate that modulation of calcium signaling by $\mathrm{CR}$ (and $\mathrm{CB}$ and $\mathrm{PV}$ ) is important for precise timing and plasticity of synaptic events in neuronal networks. To make things more complicated, it seems that $\mathrm{CR}$, similarly to $\mathrm{CB}$, might also act as a calcium sensor protein (BillingMarczak and Kuznicki 1999).

Another still controversial topic is the possible neuroprotective role of $\mathrm{CR}$. While some studies performed mainly on isolated cells or tissue cultures found neuroprotective effect against calcium-induced cytotoxicity (Lukas and Jones 1994, Isaacs et al. 1996, Marini et al. 1997, D'Orlando et al. 2001, 2002), other works using similar techniques gave opposite results (Mockel and Fischer 1994, Kuznicki et al. 1996, Bouilleret et al. 2000, Isaacs et al. 2000). Finally, neuroprotective effect of $\mathrm{CR}$ against cellular damage mediated by very low $\mathrm{Ca}^{2+}$ concentration has been described recently (Lema Tome et al. 2006, Turner et al. 2007).

\section{Calretinin-expressing neurons in the neocortex}

After the discovery of calretinin (Rogers 1987), a basic description of $\mathrm{CR}$ distribution in rodent brain emerged in the following years from the work of several authors (Pochet et al. 1989, Winsky et al. 1989, Rogers et al. 1990, Jacobowitz and Winsky 1991, Resibois and Rogers 1992) as reviewed by Baimbridge et al. (1992) and Andressen et al. (1993).

In this paper, the neurons expressing $\mathrm{CR}$ will uniformly be described as $\mathrm{CR}+$ neurons, regardless of the method used for CR detection in the particular cited articles (immunohistochemistry, in situ hybridization etc.). In this review, we will focus mainly on $\mathrm{CR}+$ neurons in rodents and primates, including human. For information about $\mathrm{CR}+$ neocortical neurons in other species and about their relationship to mammalian brain phylogenesis, see (Hof et al. 1999). 
Ontogenesis of neocortical calretinin-expressing interneurons

At least in rodents, the $\mathrm{CR}+$ interneurons differ from other interneuronal subtypes in their site of origin. Unlike the pyramidal neurons, which originate in the ventricular zone of the dorsal telencephalon, the precursors of neocortical interneurons proliferate in the ganglionic eminences in the ventral telencephalon and migrate tangentially to neocortex during the embryonic period. While the $\mathrm{PV}+$ and $\mathrm{CB}+$ cells derive predominantly from the medial ganglionic eminence, the $\mathrm{CR}+$ neurons develop in the caudal ganglionic eminence (Xu et al. 2003, Wonders and Anderson 2006). While the molecular mechanisms of $\mathrm{CR}+$ interneuronal development and migration are not completely understood yet, the attention was recently drawn to the importance of estrogen receptor $\beta$ expression for the development of $\mathrm{CR}+$ GABAergic interneurons in rodent brain (Fan et al. 2006).

Co-expression of other markers in calretinin-expressing neurons

As already mentioned in the introduction, the three calcium-binding proteins - $\mathrm{CR}, \mathrm{PV}$ and $\mathrm{CB}$ - tend to be expressed in non-overlapping populations of cortical interneurons (Conde et al. 1994, Kubota et al. 1994, Gabbott and Bacon 1996a, del Rio and DeFelipe 1996, Kawaguchi and Kubota 1997, Zaitsev et al. 2005, 2009). However, a low degree of co-localization between CR and CB was described by some authors (del Rio and DeFelipe 1996, 1997a, Cauli et al. 1997, Park et al. 2002) (for review see DeFelipe 1997). Nevertheless, the usefulness of utilization of $\mathrm{PV}, \mathrm{CB}$ and $\mathrm{CR}$ for categorizing of interneuronal subpopulations was recently validated by gene cluster analysis (Toledo-Rodriguez et al. 2004).

In rodents, almost $100 \%$ of $\mathrm{CR}+$ neurons in the neocortex seem to use GABA as a neurotransmitter (Kubota et al. 1994, Gonchar and Burkhalter 1997, Gonchar et al. 2007). On the other hand, in monkey (Melchitzky et al. 2005) and human (del Rio and DeFelipe 1996) neocortex, about $25 \%$ of CR+ neurons were found not to express GABA. These non-GABAergic $\mathrm{CR}+$ neurons are discussed below.

Substantial co-localization of CR with vasoactive intestinal peptide (VIP) and choline acetyltransferase (ChAT) in neocortical neurons was described (Rogers 1992, Kubota et al. 1994, Cauli et al. 1997, Kawaguchi and Kubota 1997, Gabbott and Bacon
1997, Porter et al. 1998, von Engelhardt et al. 2007). As long as both VIP and acetylcholine are involved in the regulation of energy metabolism and blood flow dynamics in the cortex (Magistretti 1990, Cauli et al. 2004), an important role of CR/VIP/ChAT-positive neurons in "the local regulation of tissue physiology within a radial column of cortex" can be presumed (Gabbott et al. 1997b, Cauli et al. 2004).

For additional information on co-expression of various neuronal substances (other neuropeptides, receptor subunits etc.) in $\mathrm{CR}+$ neurons, consult following papers (Rogers 1992, DeFelipe 1993, Dun et al. 1994, Cauli et al. 2000, Gonzalez-Albo et al. 2001, ToledoRodriguez et al. 2004, 2005, Gonchar et al. 2007).

Distribution and somatodendritic morphology of calretinin-expressing neurons in the neocortex

$\mathrm{CR}+$ neurons in neocortex are concentrated predominantly in cortical layers II and III, both in rodents and primates. The density of $\mathrm{CR}+$ neurons decreases with increasing depth in neocortex and therefore they are quite rare in infragranular layers, when compared to the supragranular ones. The $\mathrm{CR}+$ neurons most commonly possess bipolar or bitufted (two tufts of dendrites originating from the opposite cellular poles) vertically oriented somatodendritic morphology, with fusiform or oval perikaryon (Jacobowitz and Winsky 1991, Resibois and Rogers 1992, Glezer et al. 1992, Kubota et al. 1994, Conde et al. 1994, Fonseca and Soriano 1995, Leuba and Saini 1996, Gabbott and Bacon 1996a, Gabbott et al. 1997a,b, Meskenaite 1997, Park et al. 2002, Gonchar and Burkhalter 2003, Zaitsev et al. 2005, 2009, Desgent et al. 2005). The dendrites often extend to layer I superficially and to infragranular layers deeply. On the contrary, the dendritic tree is quite narrow in horizontal direction. Besides these bipolar neurons, other morphological types of $\mathrm{CR}+$ neurons, most typically multipolar and horizontally oriented neurons, were consistently found in the neocortex in the majority of the above cited studies (Fig. 1).

\section{Interareal and interspecies differencies}

The distribution of $\mathrm{CR}+$ neurons is similar but not absolutely homogenous among various neocortical areas. In owl monkey, $\mathrm{CR}+$ neuronal density varies between individual areas with higher values in the visual cortices, lower counts in the prefrontal association cortex and the motor and premotor cortices and lowest counts in the primary somatosensory cortex (Elston and Gonzalez- 


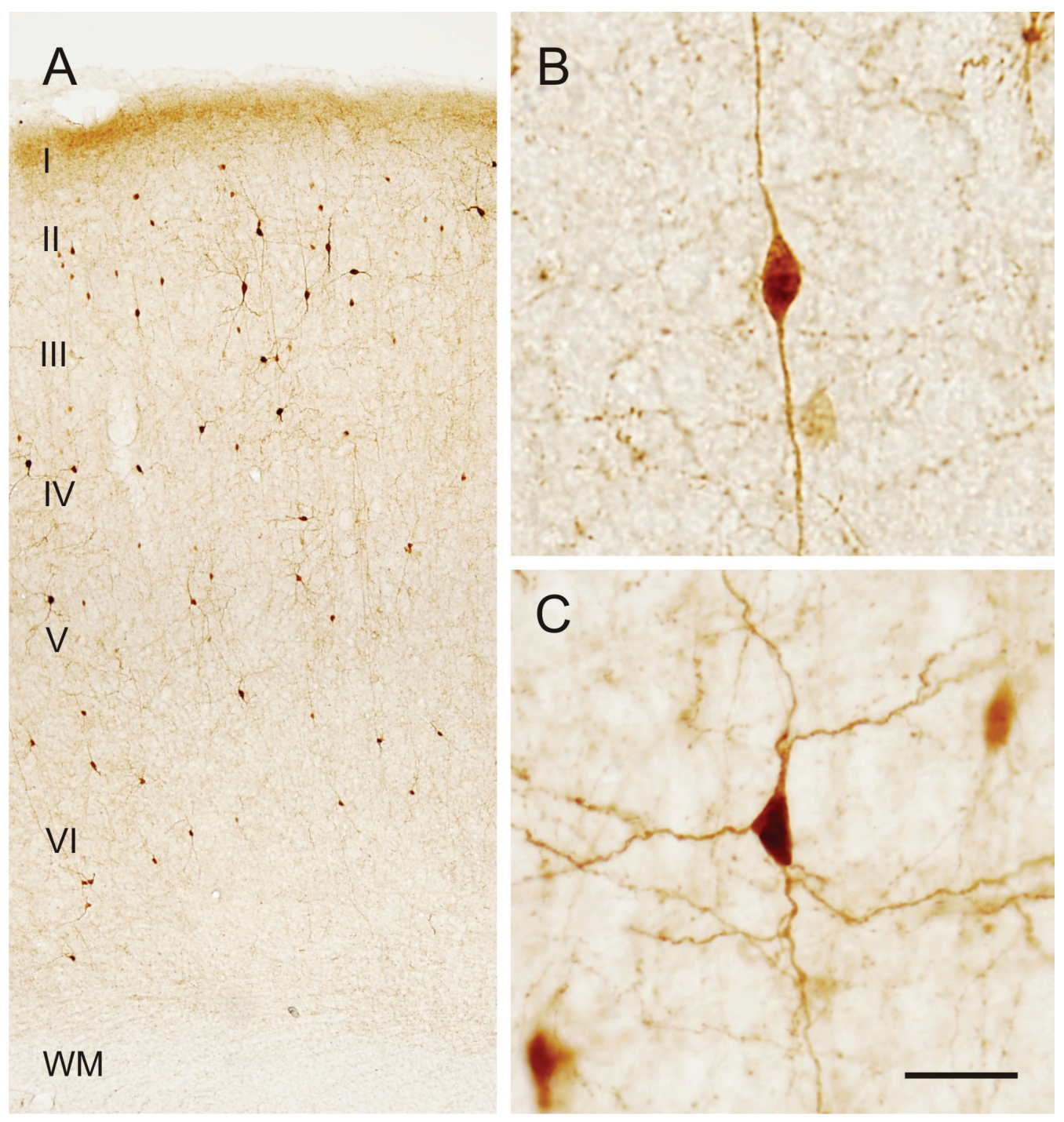

Fig. 1. Representative photomicrograph illustrating the distribution of calretinin-immunoreactive $(C R+)$ neurons in neocortex of the rat (A). Examples of typical bipolar (B) and multipolar (C) CR+ neurons. Scale bar $=200 \mu \mathrm{m}$ in A and $25 \mu \mathrm{m}$ in B and C; I-VI: cortical layers; WM: white matter.

Albo 2003). In human, although the general pattern of CR immunoreactivity was found to be similar in all inspected association areas, the density of $\mathrm{CR}+$ neurons was significantly lower in the frontal than in the temporal, occipital and parietal association cortices (Hof et al. 1993, Barinka et al. 2009).

Gabbott and coworkers systematically described morphology and distribution of $\mathrm{CR}+$ neurons in the medial prefrontal cortex (mPFC; Brodmann areas 24, 25 and 32) of the rat (Gabbott et al. 1997a), monkey (Gabbott and Bacon 1996a,b) and human (Gabbott et al. 1997b). Their work confirmed the overall resemblance of neocortical $\mathrm{CR}+$ population among examined species. However, significant difference in overall $\mathrm{CR}+$ neuronal counts between the rat neocortex on one hand and primate (monkey and human) on the other was documented. In mPFC, the $\mathrm{CR}+$ neurons constituted $4 \%$ of the total neuronal population in the rat, but $11 \%$ in the monkey and $8 \%$ in the human. Furthermore, the ratio between $\mathrm{CR}+, \mathrm{PV}+$ and $\mathrm{CB}+$ cells in $\mathrm{mPFC}$ was found to be about $1.2: 1.7: 1$ in the rat, but $2.2: 1.2: 1$ in the monkey. These results correspond well with the findings of other authors (Conde et al. 1994, Kubota et al. 1994, del Rio and DeFelipe 1996, Gonchar and Burkhalter 1997, Tamamaki et al. 2003). Altogether, the CR+ neurons are significantly more numerous in primate frontal cortex when compared to rodents, both absolutely and relatively to the other GABA+ interneuronal types. This seems to be also true in other neocortical fields, e.g. in parietal and temporal associational areas (our unpublished observation in human and rat neocortex). 
Connectivity and physiological properties of calretininexpressing neurons

For determination of individual interneuronal types, the axonal targeting and the connectivity in general are the most relevant indicators (Markram et al. 2004). In case of $\mathrm{CR}+$ neocortical neurons, the axon most typically originates from the body or one of the primary dendrites and then forms the descending main trunk with side branches with descending and ascending projection; the tangentially pointing branches are rare and the whole axonal tree usually does not extend beyond the width of the dendritic tree of that particular neuron. However, in vertical direction the axonal tree of one $\mathrm{CR}+$ neuron often spans significant portion of the cortical thickness, in case of the neurons located in supragranular layers also extending to the layers IV, V and VI. It means that the most often found $\mathrm{CR}+$ cells, which possess vertically oriented bipolar or bitufted dendritic branching, also have a similarly oriented axonal arbor (Conde et al. 1994, Fonseca and Soriano 1995, Gabbott and Bacon 1996a, Gabbott et al. 1997a,b, Meskenaite 1997, Gonchar and Burkhalter 1999, 2003, Zaitsev et al. 2005, Caputi et al. 2009). Therefore a possible role of these neurons could be to provide the inhibition of projection neurons within the cortical minicolumn and thus to synchronize their activity (Gabbott et al. 1997b). One special type of vertically oriented bitufted neurons with especially extensive vertical axonal arborisation (so-called horsetail) extending deep to the infragranular layers are the double-bouquet cells. In primates, including human (but not in rodents), some of these neurons were found to express calretinin (Conde et al. 1994, del Rio and DeFelipe 1997a, DeFelipe et al. 1999).

Besides the $\mathrm{CR}+$ neurons with vertically oriented axonal tree, cells with horizontal axonal arborisation (most often with multipolar dendritic morphology) have also been found (Meskenaite 1997, Gabbott et al. 1997b). Recently, two different types of $\mathrm{CR}+$ neurons in layers II/III in the mouse neocortex were described (Caputi et al. 2009). The first type was the CR+ bipolar neuron with vertically arranged dendritic and axonal arbors, but the second type was multipolar with preferentially horizontal orientation of both the dendritic and the axonal arbors. The bipolar neurons also uniformly co-expressed VIP, which was not found in multipolar $\mathrm{CR}+$ cell in this study. The two types clearly differ in electrophysiological characteristics as well (see below). It means that at least two significantly different populations of $\mathrm{CR}+$ neurons exist in the neocortex (besides Cajal-
Retzius cells, see below).

On the basis of their axon targeting, cortical interneurons can be divided into dendrite-targeting (with many subgroups), soma-targeting and axon-targeting interneurons. The $\mathrm{CR}+$ neurons are mostly dendrite targeting, similarly as $\mathrm{CB}+$ neurons, but unlike $\mathrm{PV}+$ neurons which typically innervate soma or axon initial segment of pyramidal neurons. More precisely, the CR+ axonal boutons that form symmetrical GABAergic synapses typically innervate dendritic shafts and less often dendritic spines or somata (Meskenaite 1997). There are noteworthy interareal differences in types of postsynaptic cells innervated by $\mathrm{CR}+$ neurons. While pyramidal neurons (especially their dendrites) were found to represent the main target of $\mathrm{CR}+$ axons in all examined layers in the human temporal neocortex (del Rio and DeFelipe 1997b), the CR+ interneurons innervate mainly pyramidal neurons in infragranular, but preferentially other GABAergic interneurons in supragranular layers of the primary visual cortex (monkey - Meskenaite 1997, rat - Gonchar and Burkhalter 1999). Also in monkey prefrontal cortex, $\mathrm{CR}+$ neurons innervate preferentially other GABAergic neurons in supragranular layers (Melchitzky and Lewis 2008). Therefore, it indicates that at least in some cortical areas and layers the $\mathrm{CR}+$ neurons (by inhibiting other classes of inhibitory interneurons) may exert significant disinhibitory effect on the pyramidal neurons (Meskenaite 1997, Gonchar and Burkhalter 1999). Based on these observations, a "gating cell" function for the $\mathrm{CR}+$ neurons - switching the flow of information between two pathways by inhibiting one of them and disinhibiting the other one - was suggested by Callaway (2004). Analogous situation was also described in the hippocampus, where $\mathrm{CR}+$ interneurons were found to be specialized to control other interneuronal types (Gulyas et al. 1996). DeFelipe et al. (1999) found in the monkey visual areas that especially the $\mathrm{CB}+$ neurons are densely contacted by $\mathrm{CR}+$ axonal terminals. On the other hand, the large PV+ basket cells did not seem to be contacted by $\mathrm{CR}+$ axonal terminals. Furthermore, the connectivity between the interneuronal populations is not unidirectional, because the $\mathrm{CR}+$ neurons were also substantially innervated by $\mathrm{PV}+$ and $\mathrm{CB}+$ interneurons.

The $\mathrm{CR}+$ interneurons are also innervated by the pyramidal cortical neurons. Interestingly, in the monkey prefrontal cortex, the density of excitatory inputs on $\mathrm{CR}+$ dendrites in supragranular layers was found to be significantly lower (40-90\%) than on the PV+ dendrites 
(Melchitzky and Lewis 2003). Similarly, in the visual areas of the rat, unlike the $\mathrm{PV}+$ neurons, the $\mathrm{CR}+$ neurons in layers II/III receive only sparse inputs from the feedback and feedforward excitatory connections (connecting primary and higher-order visual areas). On the contrary, the $\mathrm{CR}+$ neurons in layer I are selectively targeted by feedback connections from higher-order visual areas (Gonchar and Burkhalter 2003).

The synaptic connections between individual interneurons of the same type were described in all interneuronal classes, including $\mathrm{CR}+$ interneurons (Gabbott and Bacon 1996a, Gabbott et al. 1997a,b, Meskenaite 1997, Gonchar and Burkhalter 1999, Melchitzky et al. 2005, Melchitzky and Lewis 2008, Caputi et al. 2009). The inhibitory interneurons also form the so-called electrical synapses or gap junctions. These are preferentially formed between interneurons of the same class and were also found to connect the $\mathrm{CR}+$ interneurons (Caputi et al. 2009). Together, the chemical and electrical synapses between $\mathrm{CR}+$ interneurons synchronize the activity of interconnected neurons, which then form a neuronal assembly that consequently modulates the activity of other interneuronal classes as well as of the pyramidal neurons in cortical microcircuits.

While the GABAergic cortical interneurons preferentially form connections with neurons in their close proximity, sparse GABAergic cells with long-range cortico-cortical projections were also found in the neocortex (Peters et al. 1990). Interestingly, $14 \%$ of GABAergic long-distance cortico-cortical neurons in the monkey were recently found to be $\mathrm{CR}+$ (none of these neurons were PV+) (Tomioka and Rockland 2007). The exact physiological function of such long-range GABAergic neurons has not been elucidated so far, but various possibly important tasks have been proposed, e.g. synchronization of multiple local neuronal networks with otherwise weakly formed interareal connections (Buzsáki 2006).

In monkey prefrontal cortex it was shown that the $\mathrm{CR}+$ neurons, unlike the other classes of GABAergic interneurons, are not contacted by dopamine terminals (Sesack et al. 1995). Nevertheless, they possess the $D_{5}$ dopamine receptors (Glausier et al. 2009), suggesting that the extrasynaptic dopamine transmission may influence $\mathrm{CR}+$ cortical neurons. On the contrary, the VIP+ and $\mathrm{CCK}+$ interneurons (the majority of which also express $\mathrm{CR}$ ) were found to be selectively excited by nicotinic receptor stimulation in the rat neocortex (Porter et al. 1999).
Besides the above discussed GABAergic $\mathrm{CR}+$ neurons forming inhibitory, symmetric synapses, non-GABAergic $\mathrm{CR}+$ cells and asymmetric excitatory $\mathrm{CR}+$ synapses were also described. In the human temporal neocortex, $26 \%$ of $\mathrm{CR}+$ neurons were found to be non-GABAergic (del Rio and DeFelipe 1996) and $31 \%$ of synapses formed by the $\mathrm{CR}+$ axon terminals were of the asymmetrical type and hence presumably excitatory (del Rio and DeFelipe 1997b). Very similarly, $23 \%$ of $\mathrm{CR}+$ cells were GABAergic and $29 \%$ of synapses formed by the $\mathrm{CR}+$ axon terminals were asymmetric in the monkey prefrontal cortex (Melchitzky et al. 2005). In the both cited studies, the $\mathrm{CR}+$ axonal terminals which formed asymmetric synapses, contacted predominantly dendritic spines.

\section{Electrophysiological properties of calretinin-expressing} neurons

The PV+ interneurons are uniformly described as fast-spiking: in response to a depolarizing current injection, they show high-frequency firing of action potentials without marked accommodation (lowering) of firing frequency. On the other hand, the $\mathrm{CR}+($ and $\mathrm{CB}+$ ) neurons belong to the non-FS cell types (interneurons exerting other than FS pattern). The non-FS interneurons are quite heterogeneous; various spiking patterns, which do not match exactly with expression of any calciumbinding proteins, have been described. In the rodent brain, the $\mathrm{CR}+$ neurons were found to belong to the regular-spiking non-pyramidal (RSNP) cells or to burstspiking non-pyramidal (BSNP) cells (Kawaguchi and Kubota 1997, Kawaguchi and Kondo 2002). Interestingly, in the already mentioned study (Caputi et al. 2009), the two different $\mathrm{CR}+$ neuron types (bipolar and multipolar) in the mouse cortical layers II/III also differed in electrophysiological properties: the bipolar neurons showed bursting firing pattern, while the multipolar neurons had a regular firing pattern. It was suggested that the multipolar $\mathrm{CR}+$ neurons together with one type of $\mathrm{PV}+$ neurons form an interneuronal network which is able to drive synchronized inhibition of pyramidal neurons. In opposite, the bipolar $\mathrm{CR}+$ neurons could act as "disinhibitory" neurons relieving pyramidal cells from inhibition.

In the rat neocortex, the $\mathrm{CR}+/ \mathrm{VIP}+$ bipolar interneurons have also been described as irregular spiking (IS): an initial burst of action potentials is followed by intermittent action potentials (Cauli et al. 1997, 2000, Porter et al. 1998). 
Toledo-Rodriguez et al. (2004) described four major clusters of ion channel genes co-expressed in cortical interneurons of the rat. Three of these clusters contained also one of the three calcium-binding proteins. The "CR cluster" expressed (besides CR) SK2, Kv3.4 and $\mathrm{Ca} \alpha \mathrm{B}$ ion channel subunits and was associated with accommodation of spiking pattern. The PV and $\mathrm{CB}$ clusters differed in both the expression of ion channel subunits and the electrophysiological properties (PV cluster was associated with fast spiking and $\mathrm{CB}$ cluster with bursting behavior).

The $\mathrm{CR}+$ neurons were described as classic accommodating/adapting in the monkey prefrontal cortex, the pattern consistent with the RSNP in the rat (Zaitsev et al. 2005, 2009). These studies also confirmed a marked correlation between the expression of calciumbinding proteins and the electrophysiological properties of interneurons.

\section{Cajal-Retzius cells}

One "special" neuronal population which also expresses $\mathrm{CR}$ is formed by the Cajal-Retzius $(\mathrm{CjR})$ cells. These cells differ significantly from the other $\mathrm{CR}+$ neuronal types in various aspects: location exclusively in the first cortical layer, their glutamatergic phenotype, specific role in cortical layers patterning, etc. Interestingly, although the number of $\mathrm{CjR}$ neurons dramatically decreases in the early postnatal period and they probably completely disappear from the rodent cortex, in the higher mammalian orders, including primates, a small but significant population of $\mathrm{CjR}$ cells can be found also in the adult neocortex (Martin et al. 1999, Ábrahám et al. 2005). For more information, consult a recent review on CjR cells (Soriano and Del Rio 2005).

Calretinin-expressing neurons in neurologic and psychiatric disorders

The possible changes in expression of calciumbinding proteins in various neurological and psychiatric disorders were studied in detail by many authors. Interestingly, while the $\mathrm{CB}$ and especially the $\mathrm{PV}$ expression or the number of $\mathrm{CB}$ and/or PV expressing neurons decreases, the $\mathrm{CR}$ expression seems not to be affected under the conditions of schizophrenia, major depression, Alzheimer disease and multiple sclerosis (Hof et al. 1993, Fonseca and Soriano 1995, Beasley et al. 2002, Hashimoto et al. 2003, Clements et al. 2008). In various epileptic conditions, the $\mathrm{CR}$ expression or number of $\mathrm{CR}+$ neocortical neurons was shown to be normal or decreased less prominently than the $\mathrm{PV}$ and $\mathrm{CB}$ expression (Garbelli et al. 1999, 2006, Zamecnik et al. 2006, Aronica et al. 2007, Barinka et al. 2009). Whether this "resistance" of $\mathrm{CR}+$ neurons results from the proposed neuroprotective role of $\mathrm{CR}$, or whether it is the specific position of these neurons in cortical microcircuits that protects them from deterioration, has not been sufficiently elucidated yet.

\section{Conclusions}

Calretinin plays a role in modulation of synaptic events and signal transduction in neuronal networks. The role of $\mathrm{CR}$ in other intracellular $\mathrm{Ca}^{2+}$ - sensitive processes and in neuroprotection is still unclear and remains to be defined. With some limitations, the calcium-binding proteins $\mathrm{CR}, \mathrm{PV}$ and $\mathrm{CB}$ can be used as convenient markers for different populations of cortical interneurons, which has already been proved by gene expression profiling, electrophysiological as well as developmental studies. The CR expressing neurons increase in number significantly in primate neocortex, when compared to rodents. In primates, they are the most numerous interneuronal population. By inhibiting other interneurons, at least some of the $\mathrm{CR}+$ interneurons are capable to exert disinhibitory effect on pyramidal neurons, a property not described in any other interneuronal population. The $\mathrm{CR}+$ neurons which coexpress VIP (and ChAT) probably play an important role in neurovascular coupling. Besides the majority of $\mathrm{CR}+$ neurons utilizing GABA as a neurotransmitter, smaller proportion of $\mathrm{CR}+$ neurons belongs to the nonGABAergic phenotype. Finally, the CR expressing neurons seem to be more resistant to various neuropathological conditions then the $\mathrm{PV}$ and $\mathrm{CB}$ interneuronal populations.

\section{Conflict of Interest}

There is no conflict of interest.

\section{Acknowledgements}

This work was supported by Grant Agency of Charles University, Grant No. 35407 and by Grant Agency of the Czech Republic, Grant No. 304/07/1137 and 309/07/1136. 


\section{References}

ÁBRAHÁM H, TÓTH Z, BARI F, DOMOKI F, SERESS L: Novel calretinin and reelin expressing neuronal population includes Cajal-Retzius-type cells in the neocortex of adult pigs. Neuroscience 136: 217-230, 2005.

ALLER MI, JONES A, MERLO D, PATERLINI M, MEYER AH, AMTMANN U, BRICKLEY S, JOLIN HE, MCKENZIE AN, MONYER H, FARRANT M, WISDEN W: Cerebellar granule cell Cre recombinase expression. Genesis 36: 97-103, 2003.

ANDRESSEN C, BLUMCKE I, CELIO MR: Calcium-binding proteins: selective markers of nerve cells. Cell Tissue Res 271: 181-208, 1993.

ARONICA E, REDEKER S, BOER K, SPLIET WG, VAN RIJEN PC, GORTER JA, TROOST D: Inhibitory networks in epilepsy-associated gangliogliomas and in the perilesional epileptic cortex. Epilepsy Res 74: 33-44, 2007.

BAIMBRIDGE KG, CELIO MR, ROGERS JH: Calcium-binding proteins in the nervous system. Trends Neurosci 15: 303-308, 1992.

BARINKA F, DRUGA R, MARUSIC P, KRSEK P, ZAMECNIK J: Calretinin immunoreactivity in focal cortical dysplasias and in non-malformed epileptic cortex. Epilepsy Res 88: 76-86, 2010.

BEARZATTO B, SERVAIS L, ROUSSEL C, GALL D, BABA-AISSA F, SCHURMANS S, DE KERCHOVE D'EXAERDE A, CHERON G, SCHIFFMANN SN: Targeted calretinin expression in granule cells of calretinin-null mice restores normal cerebellar functions. FASEB J 20: 380-382, 2006.

BEASLEY CL, ZHANG ZJ, PATTEN I, REYNOLDS GP: Selective deficits in prefrontal cortical GABAergic neurons in schizophrenia defined by the presence of calcium-binding proteins. Biol Psychiatry 52: 708-715, 2002.

BERRIDGE MJ, LIPP P, BOOTMAN MD: The versatility and universality of calcium signalling. Nat Rev Mol Cell Biol 1: 11-21, 2000.

BILLING-MARCZAK K, KUZNICKI J: Calretinin - sensor or buffer - function still unclear. Pol J Pharmacol 51: 173-178, 1999.

BOUILLERET V, SCHWALLER B, SCHURMANS S, CELIO MR, FRITSCHY JM: Neurodegenerative and morphogenic changes in a mouse model of temporal lobe epilepsy do not depend on the expression of the calcium-binding proteins parvalbumin, calbindin, or calretinin. Neuroscience 97: 47-58, 2000.

BUZSÁKI G: Rhythms of the Brain. Oxford University Press, Oxford, 2006.

CALLAWAY EM: Feedforward, feedback and inhibitory connections in primate visual cortex. Neural Netw 17: 625632, 2004.

CAPUTI A, ROZOV A, BLATOW M, MONYER H: Two calretinin-positive GABAergic cell types in layer 2/3 of the mouse neocortex provide different forms of inhibition. Cereb Cortex 19: 1345-1359, 2009.

CARAFOLI E, SANTELLA L, BRANCA D, BRINI M: Generation, control, and processing of cellular calcium signals. Crit Rev Biochem Mol Biol 36: 107-260, 2001.

CAULI B, AUDINAT E, LAMBOLEZ B, ANGULO MC, ROPERT N, TSUZUKI K, HESTRIN S, ROSSIER J: Molecular and physiological diversity of cortical nonpyramidal cells. J Neurosci 17: 3894-3906, 1997.

CAULI B, PORTER JT, TSUZUKI K, LAMBOLEZ B, ROSSIER J, QUENET B, AUDINAT E: Classification of fusiform neocortical interneurons based on unsupervised clustering. Proc Natl Acad Sci U S A 97: 6144-6149, 2000.

CAULI B, TONG XK, RANCILLAC A, SERLUCA N, LAMBOLEZ B, ROSSIER J, HAMEL E: Cortical GABA interneurons in neurovascular coupling: relays for subcortical vasoactive pathways. $J$ Neurosci 24: 8940-8949, 2004.

CLEMENTS RJ, MCDONOUGH J, FREEMAN EJ: Distribution of parvalbumin and calretinin immunoreactive interneurons in motor cortex from multiple sclerosis post-mortem tissue. Exp Brain Res 187: 459-465, 2008.

CONDE F, LUND JS, JACOBOWITZ DM, BAIMBRIDGE KG, LEWIS DA: Local circuit neurons immunoreactive for calretinin, calbindin D-28k or parvalbumin in monkey prefrontal cortex: distribution and morphology. J Comp Neurol 341: 95-116, 1994.

D'ORLANDO C, CELIO MR, SCHWALLER B: Calretinin and calbindin D-28k, but not parvalbumin protect against glutamate-induced delayed excitotoxicity in transfected N18-RE 105 neuroblastoma-retina hybrid cells. Brain Res 945: 181-190, 2002. 
D'ORLANDO C, FELlAY B, SCHWALlER B, SAliCiO V, BLOC A, GOTZOS V, CELIO MR: Calretinin and calbindin D-28k delay the onset of cell death after excitotoxic stimulation in transfected P19 cells. Brain Res 909: $145-158,2001$.

DEFELIPE J: Neocortical neuronal diversity: chemical heterogeneity revealed by colocalization studies of classic neurotransmitters, neuropeptides, calcium-binding proteins, and cell surface molecules. Cereb Cortex 3: 273289, 1993.

DEFELIPE J: Types of neurons, synaptic connections and chemical characteristics of cells immunoreactive for calbindin-D28K, parvalbumin and calretinin in the neocortex. J Chem Neuroanat 14: 1-19, 1997.

DEFELIPE J, GONZALEZ-ALBO MC, DEL RIO MR, ELSTON GN: Distribution and patterns of connectivity of interneurons containing calbindin, calretinin, and parvalbumin in visual areas of the occipital and temporal lobes of the macaque monkey. J Comp Neurol 412: 515-526, 1999.

DEL RIO MR, DEFELIPE J: Colocalization of calbindin D-28k, calretinin, and GABA immunoreactivities in neurons of the human temporal cortex. J Comp Neurol 369: 472-482, 1996.

DEL RIO MR, DEFELIPE J: Double bouquet cell axons in the human temporal neocortex: relationship to bundles of myelinated axons and colocalization of calretinin and calbindin D-28k immunoreactivities. J Chem Neuroanat 13: 243-251, 1997a.

DEL RIO MR, DEFELIPE J: Synaptic connections of calretinin-immunoreactive neurons in the human neocortex. J Neurosci 17: 5143-5154, 1997b.

DESGENT S, BOIRE D, PTITO M: Distribution of calcium binding proteins in visual and auditory cortices of hamsters. Exp Brain Res 163: 159-172, 2005.

DUN NJ, HUANG R, DUN SL, FORSTERMANN U: Infrequent co-localization of nitric oxide synthase and calcium binding proteins immunoreactivity in rat neocortical neurons. Brain Res 666: 289-294, 1994.

EDMONDS B, REYES R, SCHWALLER B, ROBERTS WM: Calretinin modifies presynaptic calcium signaling in frog saccular hair cells. Nat Neurosci 3: 786-790, 2000.

ELSTON GN, GONZALEZ-ALBO MC: Parvalbumin-, calbindin-, and calretinin-immunoreactive neurons in the prefrontal cortex of the owl monkey (Aotus trivirgatus): a standardized quantitative comparison with sensory and motor areas. Brain Behav Evol 62: 19-30, 2003.

FAAS GC, SCHWALLER B, VERGARA JL, MODY I: Resolving the fast kinetics of cooperative binding: $\mathrm{Ca}^{2+}$ buffering by calretinin. PLoS Biol 5: e311, 2007.

FAN X, WARNER M, GUSTAFSSON J-Å: Estrogen receptor $\beta$ expression in the embryonic brain regulates development of calretinin-immunoreactive GABAergic interneurons. Proc Natl Acad Sci USA 103: 1933819343, 2006.

FONSECA M, SORIANO E: Calretinin-immunoreactive neurons in the normal human temporal cortex and in Alzheimer's disease. Brain Res 691: 83-91, 1995.

GABBOTT PL, BACON SJ: Local circuit neurons in the medial prefrontal cortex (areas 24a,b,c, 25 and 32 ) in the monkey: I. Cell morphology and morphometrics. J Comp Neurol 364: 567-608, 1996a.

GABBOTT PL, BACON SJ: Local circuit neurons in the medial prefrontal cortex (areas 24a,b,c, 25 and 32 ) in the monkey: II. Quantitative areal and laminar distributions. J Comp Neurol 364: 609-636, $1996 \mathrm{~b}$.

GABBOTT PL, BACON SJ: Vasoactive intestinal polypeptide containing neurones in monkey medial prefrontal cortex (mPFC): colocalisation with calretinin. Brain Res 744: 179-184, 1997.

GABBOTT PL, DICKIE BG, VAID RR, HEADLAM AJ, BACON SJ: Local-circuit neurones in the medial prefrontal cortex (areas 25, 32 and 24b) in the rat: morphology and quantitative distribution. J Comp Neurol 377: 465499, 1997a.

GABBOTT PL, JAYS PR, BACON SJ: Calretinin neurons in human medial prefrontal cortex (areas 24a,b,c, 32', and 25). J Comp Neurol 381: 389-410, 1997b.

GALL D, ROUSSEL C, SUSA I, D'ANGELO E, ROSSI P, BEARZATTO B, GALAS MC, BLUM D, SCHURMANS S, SCHIFFMANN SN: Altered neuronal excitability in cerebellar granule cells of mice lacking calretinin. J Neurosci 23: 9320-9327, 2003. 
GARBELLI R, MERONI A, MAGNAGHI G, BEOLCHI MS, FERRARIO A, TASSI L, BRAMERIO M, SPREAFICO R: Architectural (Type IA) focal cortical dysplasia and parvalbumin immunostaining in temporal lobe epilepsy. Epilepsia 47: 1074-1078, 2006.

GARBELLI R, MUNARI C, DE BIASI S, VITELLARO-ZUCCARELlO L, GALLI C, BRAMERIO M, MAI R, BATTAGLIA G, SPREAFICO R: Taylor's cortical dysplasia: a confocal and ultrastructural immunohistochemical study. Brain Pathol 9: 445-461, 1999.

GLAUSIER JR, KHAN ZU, MULY EC: Dopamine D1 and D5 receptors are localized to discrete populations of interneurons in primate prefrontal cortex. Cereb Cortex 19: 1820-1834, 2009.

GLEZER, II, HOF PR, MORGANE PJ: Calretinin-immunoreactive neurons in the primary visual cortex of dolphin and human brains. Brain Res 595: 181-188, 1992.

GONCHAR Y, BURKHALTER A: Three distinct families of GABAergic neurons in rat visual cortex. Cereb Cortex 7: 347-358, 1997.

GONCHAR Y, BURKHALTER A: Connectivity of GABAergic calretinin-immunoreactive neurons in rat primary visual cortex. Cereb Cortex 9: 683-696, 1999.

GONCHAR Y, BURKHALTER A: Distinct GABAergic targets of feedforward and feedback connections between lower and higher areas of rat visual cortex. J Neurosci 23: 10904-10912, 2003.

GONCHAR Y, WANG Q, BURKHALTER A: Multiple distinct subtypes of GABAergic neurons in mouse visual cortex identified by triple immunostaining. Front Neuroanat 1: 3, 2007.

GONZALEZ-ALBO MC, ELSTON GN, DEFELIPE J: The human temporal cortex: characterization of neurons expressing nitric oxide synthase, neuropeptides and calcium-binding proteins, and their glutamate receptor subunit profiles. Cereb Cortex 11: 1170-1181, 2001.

GROVES P, PALCZEWSKA M: Cation binding properties of calretinin, an EF-hand calcium-binding protein. Acta Biochim Pol 48: 113-119, 2001.

GULYAS AI, HAJOS N, FREUND TF: Interneurons containing calretinin are specialized to control other interneurons in the rat hippocampus. J Neurosci 16: 3397-3411, 1996.

GURDEN H, SCHIFFMANN SN, LEMAIRE M, BOHME GA, PARMENTIER M, SCHURMANS S: Calretinin expression as a critical component in the control of dentate gyrus long-term potentiation induction in mice. Eur J Neurosci 10: 3029-3033, 1998.

HACK NJ, WRIDE MC, CHARTERS KM, KATER SB, PARKS TN: Developmental changes in the subcellular localization of calretinin. $J$ Neurosci 20: RC67, 2000.

HACKNEY CM, MAHENDRASINGAM S, PENN A, FETTIPLACE R: The concentrations of calcium buffering proteins in mammalian cochlear hair cells. $J$ Neurosci 25: 7867-7875, 2005.

HASHIMOTO T, VOLK DW, EGGAN SM, MIRNICS K, PIERRI JN, SUN Z, SAMPSON AR, LEWIS DA: Gene expression deficits in a subclass of GABA neurons in the prefrontal cortex of subjects with schizophrenia. J Neurosci 23: 6315-6326, 2003.

HOF PR, GLEZER, II, CONDE F, FLAGG RA, RUBIN MB, NIMCHINSKY EA, VOGT WEISENHORN DM: Cellular distribution of the calcium-binding proteins parvalbumin, calbindin, and calretinin in the neocortex of mammals: phylogenetic and developmental patterns. J Chem Neuroanat 16: 77-116, 1999.

HOF PR, NIMCHINSKY EA, CELIO MR, BOURAS C, MORRISON JH: Calretinin-immunoreactive neocortical interneurons are unaffected in Alzheimer's disease. Neurosci Lett 152: 145-148, 1993.

CHERON G, GALL D, SERVAIS L, DAN B, MAEX R, SCHIFFMANN SN: Inactivation of calcium-binding protein genes induces $160 \mathrm{~Hz}$ oscillations in the cerebellar cortex of alert mice. J Neurosci 24: 434-441, 2004.

CHERON G, SERVAIS L, DAN B, GALL D, ROUSSEL C, SCHIFFMANN SN: Fast oscillation in the cerebellar cortex of calcium binding protein-deficient mice: a new sensorimotor arrest rhythm. Prog Brain Res 148: 165$180,2005$.

ISAACS KR, DE ERAUSQUIN G, STRAUSS KI, JACOBOWITZ DM, HANBAUER I: Differential effects of excitatory amino acids on mesencephalic neurons expressing either calretinin or tyrosine hydroxylase in primary cultures. Brain Res Mol Brain Res 36: 114-126, 1996.

ISAACS KR, WOLPOE ME, JACOBOWITZ DM: Vulnerability to calcium-induced neurotoxicity in cultured neurons expressing calretinin. Exp Neurol 163: 311-323, 2000. 
JACOBOWITZ DM, WINSKY L: Immunocytochemical localization of calretinin in the forebrain of the rat. $J$ Comp Neurol 304: 198-218, 1991.

KAWAGUCHI Y, KONDO S: Parvalbumin, somatostatin and cholecystokinin as chemical markers for specific GABAergic interneuron types in the rat frontal cortex. J Neurocytol 31: 277-287, 2002.

KAWAGUCHI Y, KUBOTA Y: GABAergic cell subtypes and their synaptic connections in rat frontal cortex. Cereb Cortex 7: 476-486, 1997.

KUBOTA Y, HATTORI R, YUI Y: Three distinct subpopulations of GABAergic neurons in rat frontal agranular cortex. Brain Res 649: 159-173, 1994.

KUZNICKI J, ISAACS KR, JACOBOWITZ DM: The expression of calretinin in transfected PC12 cells provides no protection against $\mathrm{Ca}^{2+}$-overload or trophic factor deprivation. Biochim Biophys Acta 1313: 194-200, 1996.

LEMA TOME CM, BAUER C, NOTTINGHAM C, SMITH C, BLACKSTONE K, BROWN L, HLAVATY C, NELSON C, DAKER R, SOLA R, MILLER R, BRYAN R, TURNER CP: MK801-induced caspase-3 in the postnatal brain: inverse relationship with calcium binding proteins. Neuroscience 141: 1351-1363, 2006.

LEUBA G, SAINI K: Calcium-binding proteins immunoreactivity in the human subcortical and cortical visual structures. Vis Neurosci 13: 997-1009, 1996.

LUKAS W, JONES KA: Cortical neurons containing calretinin are selectively resistant to calcium overload and excitotoxicity in vitro. Neuroscience 61: 307-316, 1994.

MAGISTRETTI PJ: VIP neurons in the cerebral cortex. Trends Pharmacol Sci 11: 250-254, 1990.

MARINI AM, STRAUSS KI, JACOBOWITZ DM: Calretinin-containing neurons in rat cerebellar granule cell cultures. Brain Res Bull 42: 279-288, 1997.

MARKRAM H, TOLEDO-RODRIGUEZ M, WANG Y, GUPTA A, SILBERBERG G, WU C: Interneurons of the neocortical inhibitory system. Nat Rev Neurosci 5: 793-807, 2004.

MARTIN R, GUTIERREZ A, PENAFIEL A, MARIN-PADILLA M, DE LA CALLE A: Persistence of Cajal-Retzius cells in the adult human cerebral cortex. An immunohistochemical study. Histol Histopathol 14: 487-490, 1999.

MELCHITZKY DS, EGGAN SM, LEWIS DA: Synaptic targets of calretinin-containing axon terminals in macaque monkey prefrontal cortex. Neuroscience 130: 185-195, 2005.

MELCHITZKY DS, LEWIS DA: Pyramidal neuron local axon terminals in monkey prefrontal cortex: differential targeting of subclasses of GABA neurons. Cereb Cortex 13: 452-460, 2003.

MELCHITZKY DS, LEWIS DA: Dendritic-targeting GABA neurons in monkey prefrontal cortex: comparison of somatostatin- and calretinin-immunoreactive axon terminals. Synapse 62: 456-465, 2008.

MESKENAITE V: Calretinin-immunoreactive local circuit neurons in area 17 of the cynomolgus monkey, Macaca fascicularis. J Comp Neurol 379: 113-132, 1997.

MOCKEL V, FISCHER G: Vulnerability to excitotoxic stimuli of cultured rat hippocampal neurons containing the calcium-binding proteins calretinin and calbindin D28K. Brain Res 648: 109-120, 1994.

MOEWS PC, KRETSINGER RH: Refinement of the structure of carp muscle calcium-binding parvalbumin by model building and difference Fourier analysis. J Mol Biol 91: 201-225, 1975.

PARK HJ, KONG JH, KANG YS, PARK WM, JEONG SA, PARK SM, LIM JK, JEON CJ: The distribution and morphology of calbindin D28K- and calretinin-immunoreactive neurons in the visual cortex of mouse. Mol Cells 14: 143-149, 2002.

PARMENTIER M, PASSAGE E, VASSART G, MATTEI MG: The human calbindin D28k (CALB1) and calretinin (CALB2) genes are located at 8q21.3----q22.1 and 16q22----q23, respectively, suggesting a common duplication with the carbonic anhydrase isozyme loci. Cytogenet Cell Genet 57: 41-43, 1991.

PETERS A, PAYNE BR, JOSEPHSON K: Transcallosal non-pyramidal cell projections from visual cortex in the cat. J Comp Neurol 302: 124-142, 1990.

POCHET R, BLACHIER F, MALAISSE W, PARMENTIER M, PASTEELS B, POHL V, RESIBOIS A, ROGERS J, ROMAN A: Calbindin-D28 in mammalian brain, retina, and endocrine pancreas: immunohistochemical comparison with calretinin. Adv Exp Med Biol 255: 435-443, 1989. 
PORTER JT, CAULI B, STAIGER JF, LAMBOLEZ B, ROSSIER J, AUDINAT E: Properties of bipolar VIPergic interneurons and their excitation by pyramidal neurons in the rat neocortex. Eur J Neurosci 10: 3617-3628, 1998.

PORTER JT, CAULI B, TSUZUKI K, LAMBOLEZ B, ROSSIER J, AUDINAT E: Selective excitation of subtypes of neocortical interneurons by nicotinic receptors. J Neurosci 19: 5228-5235, 1999.

RESIBOIS A, ROGERS JH: Calretinin in rat brain: an immunohistochemical study. Neuroscience 46: 101-134, 1992.

ROGERS J, KHAN M, ELLIS J: Calretinin and other CaBPs in the nervous system. Adv Exp Med Biol 269: 195-203, 1990.

ROGERS JH: Calretinin: a gene for a novel calcium-binding protein expressed principally in neurons. J Cell Biol 105: 1343-1353, 1987.

ROGERS JH: Immunohistochemical markers in rat cortex: co-localization of calretinin and calbindin-D28k with neuropeptides and GABA. Brain Res 587: 147-157, 1992.

SESACK SR, BRESSLER CN, LEWIS DA: Ultrastructural associations between dopamine terminals and local circuit neurons in the monkey prefrontal cortex: a study of calretinin-immunoreactive cells. Neurosci Lett 200: 9-12, 1995.

SCHIFFMANN SN, CHERON G, LOHOF A, D'ALCANTARA P, MEYER M, PARMENTIER M, SCHURMANS S: Impaired motor coordination and Purkinje cell excitability in mice lacking calretinin. Proc Natl Acad Sci US A 96: 5257-5262, 1999.

SCHURMANS S, SCHIFFMANN SN, GURDEN H, LEMAIRE M, LIPP HP, SCHWAM V, POCHET R, IMPERATO A, BOHME GA, PARMENTIER M: Impaired long-term potentiation induction in dentate gyrus of calretinin-deficient mice. Proc Natl Acad Sci USA 94: 10415-10420, 1997.

SCHWALLER B: The continuing disappearance of "pure" $\mathrm{Ca}^{2+}$ buffers. Cell Mol Life Sci 66: 275-300, 2009.

SCHWALLER B, DURUSSEL I, JERMANN D, HERRMANN B, COX JA: Comparison of the Ca ${ }^{2+}$-binding properties of human recombinant calretinin-22k and calretinin. J Biol Chem 272: 29663-29671, 1997.

SORIANO E, DEL RIO JA: The cells of Cajal-Retzius: still a mystery one century after. Neuron 46: 389-394, 2005.

STEVENS J, ROGERS JH: Chick calretinin: purification, composition, and metal binding activity of native and recombinant forms. Protein Expr Purif 9: 171-181, 1997.

TAMAMAKI N, YANAGAWA Y, TOMIOKA R, MIYAZAKI J, OBATA K, KANEKO T: Green fluorescent protein expression and colocalization with calretinin, parvalbumin, and somatostatin in the GAD67-GFP knock-in mouse. J Comp Neurol 467: 60-79, 2003.

TOLEDO-RODRIGUEZ M, BLUMENFELD B, WU C, LUO J, ATTALI B, GOODMAN P, MARKRAM H: Correlation maps allow neuronal electrical properties to be predicted from single-cell gene expression profiles in rat neocortex. Cereb Cortex 14: 1310-1327, 2004.

TOLEDO-RODRIGUEZ M, GOODMAN P, ILLIC M, WU C, MARKRAM H: Neuropeptide and calcium-binding protein gene expression profiles predict neuronal anatomical type in the juvenile rat. J Physiol Lond 567: 401413, 2005.

TOMIOKA R, ROCKLAND KS: Long-distance corticocortical GABAergic neurons in the adult monkey white and gray matter. J Comp Neurol 505: 526-538, 2007.

TURNER CP, CONNELL J, BLACKSTONE K, RINGLER SL: Loss of calcium and increased apoptosis within the same neuron. Brain Res 1128: 50-60, 2007.

VON ENGELHARDT J, ELIAVA M, MEYER AH, ROZOV A, MONYER H: Functional characterization of intrinsic cholinergic interneurons in the cortex. J Neurosci 27: 5633-5642, 2007.

WINSKY L, NAKATA H, MARTIN BM, JACOBOWITZ DM: Isolation, partial amino acid sequence, and immunohistochemical localization of a brain-specific calcium-binding protein. Proc Natl Acad Sci USA 86: 10139-10143, 1989.

WONDERS CP, ANDERSON SA: The origin and specification of cortical interneurons. Nat Rev Neurosci 7: 687-696, 2006.

XU Q, DE LA CRUZ E, ANDERSON SA: Cortical interneuron fate determination: diverse sources for distinct subtypes? Cereb Cortex 13: 670-676, 2003. 
ZAITSEV AV, GONZALEZ-BURGOS G, POVYSHEVA NV, KRONER S, LEWIS DA, KRIMER LS: Localization of calcium-binding proteins in physiologically and morphologically characterized interneurons of monkey dorsolateral prefrontal cortex. Cereb Cortex 15: 1178-1186, 2005.

ZAITSEV AV, POVYSHEVA NV, GONZALEZ-BURGOS G, ROTARU D, FISH KN, KRIMER LS, LEWIS DA: Interneuron diversity in layers 2-3 of monkey prefrontal cortex. Cereb Cortex 19: 1597-1615, 2009.

ZAMECNIK J, KRSEK P, DRUGA R, MARUSIC P, BENES V, TICHY M, KOMAREK V: Densities of parvalbuminimmunoreactive neurons in non-malformed hippocampal sclerosis-temporal neocortex and in cortical dysplasias. Brain Res Bull 68: 474-481, 2006. 